Plant Tissue Cult. \& Biotech. 31(1): 51-60, 2021 (June)

(C)Bangladesh Assoc. for Plant Tissue Culture \& Biotechnology

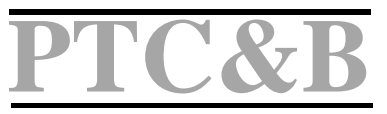

\title{
Mass Propagation of Nauclea diderrichii (de Willd. \& Th. Dur) Merr. Seedlings through Tissue Culture Technique
}

\author{
R.I. Oyediran, J.O. Afolabi*, D.B. Olomola and F.O. Akanni \\ Forestry Research Institute of Nigeria, PMB 5054, Jericho Hill, Ibadan, Nigeria \\ Key words: Acclimatization, Coconut-husk, Mass-propagation, Plantlets, Tissue-culture
}

\begin{abstract}
Nauclea diderrichii is a tree species of economic importance. However, its plantation establishment is limited by inadequate seedling production. Hence, there is ample scope of tissue culture for its mass propagation. Its in vitro plantlets development as affected by media strengths indicated that $100 \%$ seed germination was obtained in full MS basal medium while the least $(3.35 \%)$ was from quarter-strength at 8 Weeks after inoculation (WAI). The effects of BAP and NAA assessed on the growth of its sub-cultured plantlets showed that highest number of leaves (17) and adventitious shoots (3) were obtained from MS basal medium supplemented with $0.1 \mathrm{mg} \Lambda$ BAP only. Whereas, highest shoot length $(3.61 \mathrm{~cm})$ and average number of roots (5/plantlet) were obtained from the same medium without hormone(s) at 8 WAI. Further sub-culturing into MS with $0.05 \mathrm{mg} /$ NAA resulted into plantlets having optimum shoot and massive root growth ready for acclimatization in 6 WAI. The plantlets were successfully acclimatized using coconuthusk/topsoil mixture with $90 \%$ survival.
\end{abstract}

\section{Introduction}

Nauclea diderrichii commonly known as Opepe belongs to the family Rubiaceae. It is a timber species indigenous to tropical rainforest of West Africa (Leakey 1990). It is one of the five local priority species used in plantations in West African sub region (Onyekwelu 2001). The species is moderately resistance to decay, stem borers and termites (Orwa et al. 2009) while different parts of the species (back, leaves, root and fruit) are loaded with a range of therapeutic compounds (Haudecoeur et al. 2018). Hence, it is harvested from the wild and used traditionally for medicinal purposes, wood and timber production. Its leaves and stem back extracts are reported for activities on metabolic disorders (Agnaniet et al. 2016, Ogbole et al. 2016). Its leave is also used for the treatment of skin disorder in keffi, Nigeria (Mustapha et al. 2013). The back and stem back are used for treatment of

*Author for correspondence: <olujames58@gmail.com>

DOI: https://doi.org/10.3329/ptcb.v31i1.54111 
female infertility (Betti 2002) and Sexual asthenia in Cameroon (Nole et al. 2016) and Gabon (Towns 2014b). The back is credited with diuretic properties and is also used as anti-diabetic, blood thinner and for anaemia in Cameroon (Ndenecho 2009; Nole et al. 2016; Laleye et al. 2015). In central Africa, N. diderrichii back, root and stem are used against fever (Eyong 2007). Its back, root and fruit are also used for tooth and back ache (Ndenecho 2009), stomach problems, dental and oral care (Betti 2002), diarrhea and gonorrhoea (Chukwuma et al. 2015). The species timber quality is rated high in terms of strength and durability and therefore used in heavy construction, joinery, flooring, plywood and many other domestic uses as well as in building industries (Orwa et al. 2009; Adjonou et al. 2014).

Due to the economic importance of $N$. diderrichii coupled with increasing population and living standards, the species is threatened by heavy exploitation and uncontrolled harvest (Keay 1964; Jusu and Sanchez 2014), hence, its "vulnerable" status on the International Union for Conservation of Nature (IUCN) Red List of threatened Species (IUCN 1998). Nonetheless, in spite of the abundance of fruits produced by the tree species yearly, regeneration by seed is very low (Pitekelabou et al. 2015). Seeds can remain dormant in soil until stimulated to germinate by increased sunlight exposure. Moreover, seedlings at early stage are susceptible to damping off as rate of growth is very low (Opuni-Frimpong and Opuni-Frimpong 2012). This necessitates artificial regeneration through in vitro propagation technique in order to evade the species from the risk of extinction (Onyekwelu et al. 2003). In-vitro vegetative micro-propagation technique allows for regeneration, multiplication and preservation of endangered species (Chen et al. 2001).

Conversely, mass propagation of tree species in vitro is faced with many challenges among which are lack of protocols and that of reproducibility of existing protocols. Till date, protocol for in vitro and mass seedling production of $N$. diderrichii is not widely available. In view of the above the present work sought to develop protocol for in-vitro propagation of the species with a view to establish suitable culture media for its plantlet establishment, determine the most suitable levels of growth regulator(s) for its shoot regeneration and proliferation, root induction and optimize potting media for the acclimatization of its in vitro generated plantlets

\section{Materials and Methods}

The study was conducted at Biotechnology Centre of Forestry Research Institute of Nigeria (FRIN). The Institute is located on longitude $07^{\circ} 23^{\prime} 18^{\prime \prime}$ to $07^{\circ} 23^{\prime} 43^{\prime \prime} \mathrm{N}$ and latitude 03'51'20" to 03'23'43"E (FRIN, 2018).

Plantlets establishment was initiated using different strengths of Murashige and Skoog media supplemented with BAP (Table 1). 
Table 1. MS media strengths for plantlets establishment.

\begin{tabular}{cc}
\hline Media strength $(\%)$ & BAP $(\mathrm{mg} \Lambda)$ \\
\hline 25 & 1 \\
50 & 1 \\
75 & 1 \\
100 & 1 \\
\hline
\end{tabular}

Shoot regeneration and root induction experiment was carried out using different treatments to determine the best. It involved MS basal medium supplimented with both BAP and NAA as stated in Table 2.

Table 2. Treatment composition for shoot regeneration and root induction.

\begin{tabular}{lcc}
\hline Treatments & BAP $(\mathrm{mg} \Lambda)$ & NAA $(\mathrm{mg} \Lambda)$ \\
\hline A & 0.0 & 0.0 \\
B & 0.0 & 0.1 \\
C & 0.1 & 0.0 \\
D & 0.2 & 0.1 \\
E & 0.3 & 0.2 \\
F & 0.4 & 0.3 \\
G & 0.5 & 0.4 \\
\hline
\end{tabular}

Both experiments were set up with 30 and 7 replicates respectively and laid out in CRD.

The different concentrations of MS basal media were prepared using $34.43 \mathrm{~g} / \mathrm{MS}$ media powder (M5501, SXS5501015A). Plant Growth Regulators (PGRs) were added accordingly as stated in Tables 1 and 2. The media $\mathrm{pH}$ was adjusted to 5.8 and gelled with $9 \mathrm{~g} /$ of Agar (Sigma Aldrich, Lot 83112) while $20 \mathrm{ml}$ was dispensed into each tube and sterilized at $121^{\circ} \mathrm{C}$ and 15 psi for 15 minutes.

Seeds were used as explant for clean plantlet establishment. Freshly collected N. diderrichii seeds were disinfected by dipping in a mixture of fungicide for 30 minutes, followed by $70 \%$ ethanol for 3 minutes and 10\% hypochlorite solution for 5 minutes. The explants were rinsed thrice after each steps and then blotted on sterile filter paper. The seeds were inoculated on the average of 5 seeds per tube, sealed and placed in the growth room under $16 / 8$ hours light/dark photoperiod.

The shoot tips and nodal segments (about $1.5 \mathrm{~cm}$ size) of grown plantlets from the first culture were subcultured for shoot regeneration/rooting experiment. Further subculturing was done using the same MS basal medium but supplemented with $0.05 \mathrm{mg} /$ NAA. 
The acclimatization of the generated plantlets was done on natural substrate containing coconut husk and topsoil at ratio 3:1. The substrate was initially sterilized in an autoclave at $121^{\circ} \mathrm{C}$ and $15 \mathrm{psi}$ for 30 minutes. The culture tubes containing the subcultured plantlets were decapped and exposed for 4 days. Fungicide was introduced into the tubes to prevent fungal attack. The mixture was moistened and filled into seedling tray while the plantlets were transplanted. The transplants were kept under mist propagator in the acclimatization chamber and sprayed regularly with fungicide solution for two weeks. At 6 weeks after transplanting, the survived transplants were transferred into polythene pots containing $1 \mathrm{~kg}$ top soil and watered regularly in the acclimatization chamber.

Data collection and collation was based on germination percentage, shoot length, number of leaves, number of adventitious shoot and number of roots at intervals of four weeks. Data collected were subjected to analysis of variance using SPSS (Edition 20). Significantly different means were separated using DMRT at $\mathrm{p} \leq 0.05$

\section{Results and Discussion}

The results showed that seed germination had started at 4 weeks after inoculation (WAI) and by 8 WAI, the results showed that MS media at full basal salt (100\%) supported the germination best having $100 \%$ (Figure 1). This was followed by $53.35 \%$ and $30 \%$ from MS $75 \%$ and $50 \%$ basal salts respectively while the least (3.35\%) was from MS $25 \%$ basal salts. Consequently, MS $100 \%$ basal salts was subsequently used for sub-culturing of the species.

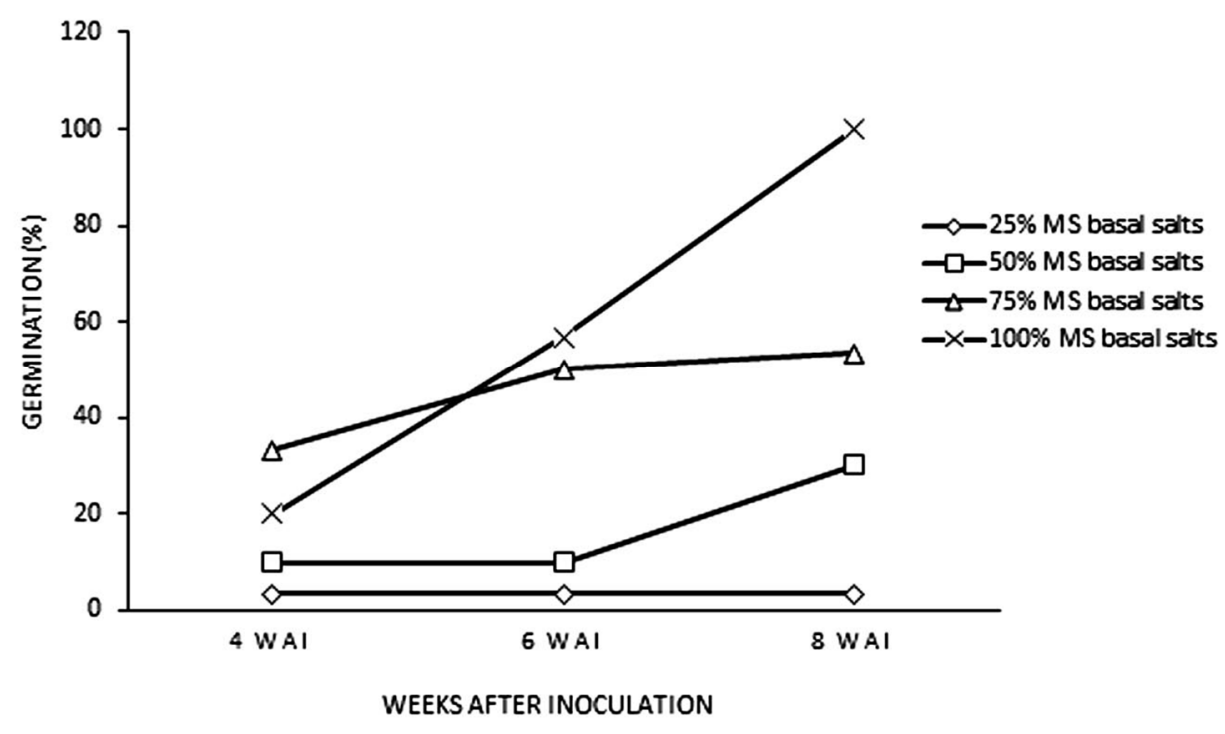

Fig. 1. Effects of different MS basal salts on in vitro germination of $N$. diderrichii seeds. 
The results indicated that Nauclea diderrichii can be successfully regenerated from seeds on high nutrient medium such as MS basal. The downward pattern of germination from the highest rate in $100 \%$ basal medium to the lowest in the $25 \%$ MS basal medium showed that the species requires high nutrient for its propagation. The availability of maximum nutrients in $100 \%$ MS basal medium could have led to highest germination rate observed at $8 \mathrm{WAI}$ (Fig. 1).

The result of the effects of BAP and NAA on in vitro shoot length of regenerated $N$. diderrichii is shown in Table 3 . Analysis of variance revealed that there was significant difference ( $\mathrm{p} \leq 0.05)$ between the means of the shoot length at 4 WAI whereas by 8 WAI, the shoot lengths were comparable between the treatments. Average of $2.8 \mathrm{~cm}$ shoot length obtained from treatment A (MS without growth regulators) was significantly higher than $1.9 \mathrm{~cm}, 1.89 \mathrm{~cm}$ and $1.49 \mathrm{~cm}$ obtained from treatments $\mathrm{E}, \mathrm{F}$ and G (media added 0.3/0.2, 0.4/0.3 and 0.5/0.4 mg $/$ BAPNAA) respectively at 4 WAI. By 8 WAI, highest shoot length of $3.61 \mathrm{~cm}$ was obtained from treatment $\mathrm{A}$ followed by D $(3.23 \mathrm{~cm})$, $B(3.11 \mathrm{~cm})$ and $C(2.90 \mathrm{~cm})$ while the least, $2.39 \mathrm{~cm}$ was from treatment G (Plate 1).

The number of roots of regenerated $N$. diderrichii plantlets as affected by BAPANA treatment is presented in Table 3. Significant difference $(p \leq 0.05)$ was observed between the plantlets roots mean difference at 4 and $8 \mathrm{WAI}$ while the results follow similar trends at both periods. Treatment A (MS without PGRs) with average of 3.71 and 5.0 roots was similar to treatment $B(2.43,3.29)$ and $C(2.14,2.29)$ at 4 and 8 WAI respectively. Moreover, it was higher than treatment D, E, F and G in between which there was no significant difference.

Table 3. Effects of BAP and NAA on shoot length and number of roots of $N$. diderrichii at successful growth weeks.

\begin{tabular}{|c|c|c|c|c|}
\hline \multirow{2}{*}{ Treatments } & \multicolumn{2}{|c|}{ Shoot length $(\mathrm{cm})$} & \multicolumn{2}{|c|}{ Number of roots } \\
\hline & $4 \mathrm{WAI}$ & $8 \mathrm{WAI}$ & $4 \mathrm{WAI}$ & 8WAI \\
\hline A & $2.80 \mathrm{a}$ & 3.61a & $3.71 \mathrm{a}$ & $5.0 \mathrm{a}$ \\
\hline B & 2.24ab & 3.11ab & $2.43 \mathrm{ab}$ & $3.29 \mathrm{ab}$ \\
\hline C & 2.34ab & $2.90 \mathrm{ab}$ & 2.14abc & $2.29 b c$ \\
\hline D & $2.14 a b c$ & $3.23 \mathrm{ab}$ & $0.43 b c$ & $0.71 b c$ \\
\hline E & $1.90 \mathrm{bc}$ & $2.60 \mathrm{ab}$ & $0 c$ & $0 c$ \\
\hline $\mathrm{F}$ & $1.89 b c$ & $2.49 \mathrm{~b}$ & $0.14 \mathrm{c}$ & $0.14 c$ \\
\hline G & $1.49 \mathrm{c}$ & $2.39 b$ & $0 c$ & $0 c$ \\
\hline
\end{tabular}

Means in the same column followed by the same alphabets are not significantly different at $(\mathrm{p} \leq$ $0.05)$. 
Table 4 showed the number of leaves of regenerated plantlets of $N$. diderrichii as affected by BAPNAA combination at successive growth weeks. There was significant difference $(p \leq 0.05)$ in the number of leaves at both periods of observation. Treatment $C$ (containing $0.1 \mathrm{mg} / \mathrm{BAP}$ only) had average of 14.6 leaves, higher than all other treatments at 4 WAI. By 8 WAI, treatment $C$ had 17 number of leaves which was comparable to treatments D (14.3) and G (13.4) while greater than others. Moreover, treatments E, F, B and A produced similar number of leaves; 12, 11.1, 8.6 and 8.3 respectively at 8 WAI (Table 4 and Plate 1 ).

The number of adventitious shoot induced by BAPNAA treatment on $N$. diderrichii plantlets as presented in Table 4 showed there was significant difference in the effects of treatments. The results also revealed that the lower the BAPNAA combinations, the more the shoot produced. Treatment $C(0.1 \mathrm{mg} / \mathrm{BAP})$ had highest number of adventitious shoots, 2.9 and 3.0 at 4 and 8 WAI respectively. These value were greater than all other treatment while treatment $\mathrm{B}(0.1 \mathrm{mg} \Lambda \mathrm{NAA})$ produced no adventitious shoots by 8 WAI (Fig. 1).

Table 4. Effects of BAP and NAA on number of leaves and number of adventitious shoots of $N$. diderrichii at successful growth weeks.

\begin{tabular}{lcccc}
\hline \multirow{2}{*}{ Treatments } & \multicolumn{2}{c}{ Number of leaves } & \multicolumn{2}{c}{ Number of Adventitious shoots } \\
\cline { 2 - 5 } & 4 WAI & 8 WAI & 4 WAI & 8 WAI \\
\hline A & $6.7 \mathrm{~cd}$ & $8.3 \mathrm{c}$ & $0.3 \mathrm{~b}$ & 0.3 \\
B & $5.4 \mathrm{~d}$ & $8.6 \mathrm{c}$ & $0.0 \mathrm{~b}$ & $0.0 \mathrm{~b}$ \\
$\mathrm{C}$ & $14.6 \mathrm{a}$ & $17.0 \mathrm{a}$ & $2.9 \mathrm{a}$ & $3.0 \mathrm{a}$ \\
$\mathrm{D}$ & $10.7 \mathrm{~b}$ & $14.3 \mathrm{ab}$ & $1.3 \mathrm{~b}$ & $1.1 \mathrm{~b}$ \\
$\mathrm{E}$ & $10.1 \mathrm{~b}$ & $12.0 \mathrm{bc}$ & $0.7 \mathrm{~b}$ & $0.7 \mathrm{~b}$ \\
F & $8.7 \mathrm{bc}$ & $11.1 \mathrm{bc}$ & $0.6 \mathrm{~b}$ & $0.6 \mathrm{~b}$ \\
G & $10 \mathrm{~b}$ & $13.4 \mathrm{ab}$ & $0.6 \mathrm{~b}$ & $0.6 \mathrm{~b}$ \\
\hline
\end{tabular}

Means in the same column followed by the same alphabets are not significantly different at $(\mathrm{p} \leq$ 0.05)

The observed better results in terms of shoot length and number of roots from MS basal medium without growth regulators in comparison to those supplemented with BAPNAA (Table 3) suggested that shoot regeneration/rooting of $N$. diderrichii plantlets could be achieved in vitro without hormones. These results corresponded with that of Afolabi et al. (2018) where $1 / 2$ strength MS medium without growth regulators elicited better growth in terms of shoot length, number of nodes and root on Moringa oleifera plantlets at 4 WAI. 
Moreover, highest number of leaves and adventitious shoots from medium containing BAP alone $(0.1 \mathrm{mg} /)$ underscored the importance of cytokinins like BAP as plants multiple shoot inducing hormone. There was no opposing effect of NAA in the medium hence, BAP had unhindered influence on the plantlets shoot formation and leave morphology which leads into highest results from the treatment at 8 WAI (Table 4 and Fig. 1C). This result could be related to the observation of Pei and Wei (2019) on Neolamarckia cadamba of the same family that $1.0 \mathrm{mg} /$ BAP used in B5 medium provided most suitable medium for shoot induction of the species nodal explants.

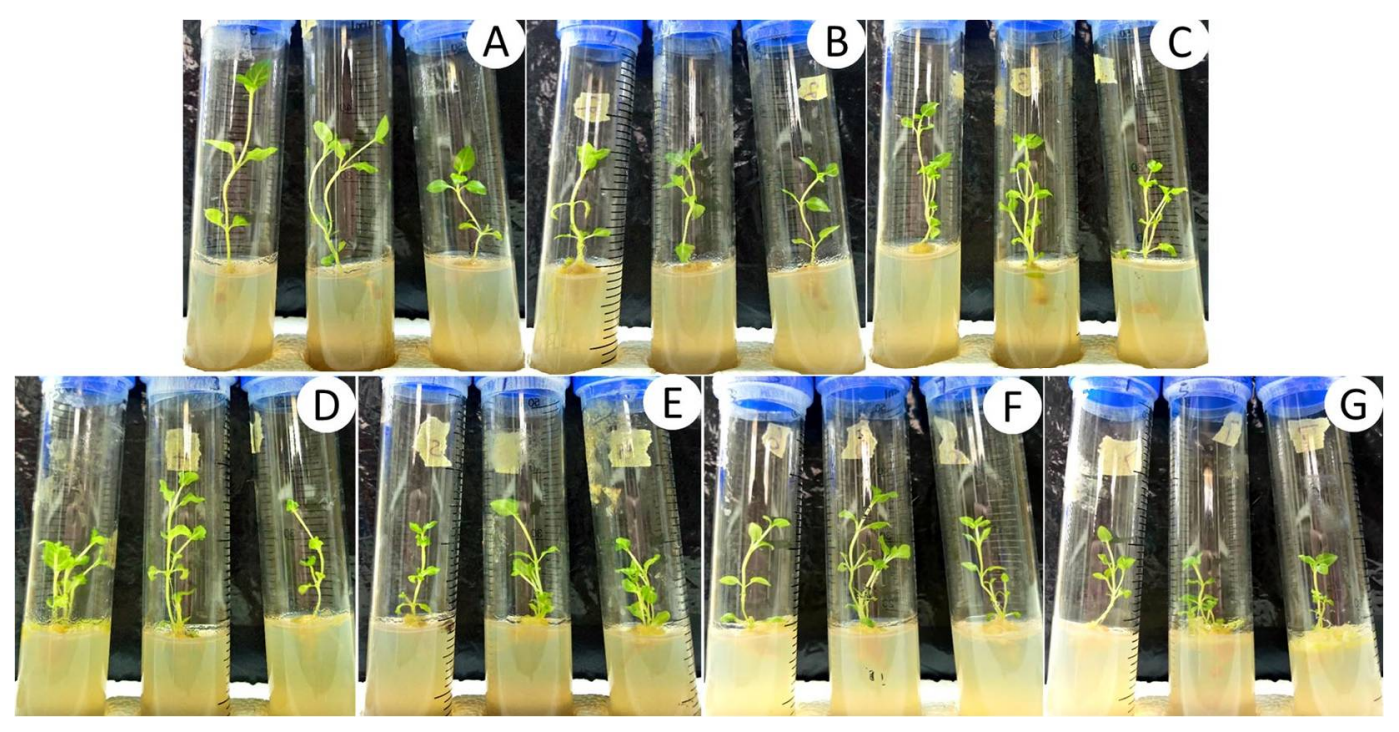

Fig. 1. Effects of BAP and NAA on in vitro growth of $N$. diderrichii at 8 WAI (A) 0.0/0.0, (B) 0.0/0.1, (C) 0.10.0, (D) 0.2/0.1, (E) 0.3/0.2, (F) 0.4/0.3 and (G) 0.5/0.4 mg/ BAP NAA

Further subculturing using the same MS medium but suplemented with $0.05 \mathrm{mg} /$ NAA resulted into complete plantlets having shoot with vigour and massive roots ready for acclimatization in six weeks (Fig. 2A). Consequently, this condition was used for mass production of the species through repeated successive sub-culturing on average of 1 plantlets to 5 tubes at interval of six weeks. This result indicated that $0.05 \mathrm{mg} / \mathrm{NAA}$ is the optimum for production of $N$. diderrichii plantlets on solid MS medium. This result is contrary to the report of Pitekelabou et al. (2015a) who stated that IBA used at $0.1 \mathrm{mg} /$ was better appropriate for improvement of $N$. diderrichii in vitro rooting. $N$. diderrichii plantlets developed in this study were successfully acclimatized on coconut husk/top soil mixture with $90 \%$ survival (Fig. 2 B) while the survived transplants were successfully potted and hardened (Fig. $2 \mathrm{C}$ ) 

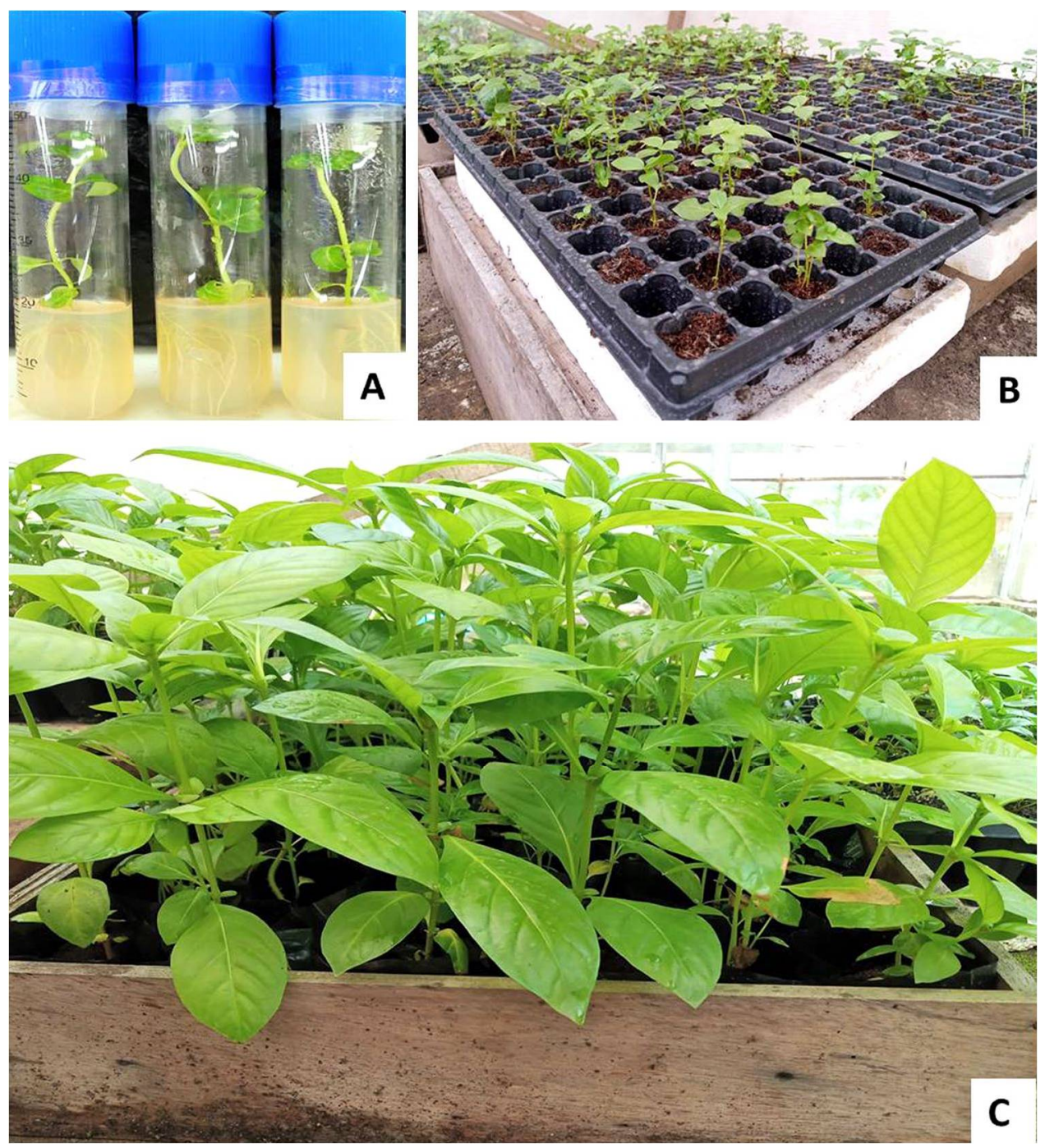

Fig. 2. A: Effects of NAA on N. diderrichii plantlets at 6 WAI. B: Survived transplanted N. diderrichii plantlets at 6 weeks after transplanting (WAT). C: Potted N. diderrichii plantlets at 8 WAT.

In conclusion, this study revealed that mass propagation of $N$. diderrichii is achievable via tissue culture technique. Disease-free plantlets were successfully established using seeds as explant on $100 \%$ MS basal medium supplemented with $1 \mathrm{mg} / \mathrm{BAP}$. Plantlets regeneration in terms of shoot length and number of roots were best achieved using MS basal medium without growth regulators whereas, shoot proliferation was best achieved on the same medium supplemented with $0.1 \mathrm{mg} /$ BAP. Acclimatisation of the plantlets was done successfully using coconut husk/top soil medium with $90 \%$ survival. Therefore, this protocol is recommended for mass propagation of Nauclea diderrichii seedlings towards plantation establishment. 


\section{References}

Adjonou K, Nuto Y, Bosu PP, Adu-BreduS, Kokutse DA and Kokou K (2014) Natural Distribution of Nauclea diderrichii (Rubiceae) in Semi Deciduous Forest of Togo (West Africa) and Implementation of Integrated Silviculture. Am. J. Plant Sci. 5: 1220-1235.

Afolabi JO, Olomola DB, Osunlaja OA, Oloyede EO and Bolanle-Ojo IO (2018) Effect of different media on seed germination and in vitro propagation of Moringa oleifera L. J. For. Res. Manag. 15(1): 13-21.

Agnaniet H, Mbot EJ, Keita O, Fehrentz JA, Ankli A, Gallud A, Garcia M, Gary-Bobo M, Lebibi J and Cresteil T (2016) Antidiabetic potential of two medicinal plants used in Gabonese folk medicine. BMC Complement. Altern. Med. 16: 1.

Betti JL (2002) Medicinal plants sold in Yaoundé markets, Cameroon. Afr. Study Monogr. 23: 47-64.

Chen CC, Suh-jau CSJ, Sagare AP and Tsay HS (2001) Adventitious shoot regeneration from stem internode explants of Adenophora triphylla (Thunb.) A. DC. (Campanulaceae)- an important medicinal herb. Bot. Bull. Acad. Sinica, 42: 1-7.

Chukwuma EC, Soladoye MO and Feyisola RT (2015) Traditional medicine and the future of medicinal Plants in Nigeria. J. Med. Plants Stud. 3: 23-29.

Eyong CT (2007) Indigenous Knowledge Systems and Sustainable Development: Relevance for Africa. In: Tribes and tribals. Kamla-Raj Enterprises, pp. 121-139.

Forestry Research Institute of Nigeria (FRIN) (2018) Meteorological Report 2017-18. Nigeria.

Haudecoeur R, Peuchmaura M, Pérèsa B, Romec M, Taïwee SG, Boumendjela A and Boucherlea B (2018) Traditional uses, phytochemistry and pharmacological properties of African Nauclea species: A review. J. Ethnopharmacol. 212(2018): 106-136.

IUCN (1998) African Regional Workshop (Conservation \& Sustainable Management of Trees, 1996). Nauclea diderrichii. The IUCN Red List of Threatened Species, 1998: e.T33058A9746387. https:dx.doi.org/10.2305/UCN.UK.1998.RLTS.T33058A9746387.en. Downloaded on 22 January 2021.

Jusu A and Sanchez AC (2014) Medicinal plant trade in Sierra Leone: threats and opportunities for conservation. Econ. Bot. 68(1): 16-29.

Keay RWJ (1964). Nigeria Trees. Oxford University Press. 1: 399.

Laleye FOA, Mensah S, Assogbadjo AE and Ahissou H (2015) Diversity, Knowledge, and Use of Plants in Traditional Treatment of Diabetes in the Republic of Benin. Ethnobot. Res. Appl. 14: 231-257.

Leakey BRR (1990) Nauclea diderrichii: rooting of stem cuttings, clonal variation in shoot dominance, and branch plagiotropism. Trees (1990) 4: 164-169.

Mustapha AA, Owuna G and Uthman IHI (2013) Plant remedies practiced by Keffi people in the management of dermatosis. J. Med. Plants 1: 112-118.

Ndenecho EN (2009) Herbalism and resources for the development of ethnopharmacology in Mount Cameroon region. Afr. J. Pharm. Pharmacol. 3: 078-086.

Nole T, Lionel TDW, Cedrix TFS and Gabriel AA (2016) Ethnomedical and ethnopharmacological study of plants used for potential treatments of diabetes and arterial hypertension by indigenous people in three phytogeographic regions of Cameroon. Diabetes Case Rep. 1: 110119. 
Ogbole OO, Aliu LO, Abiodun OO and Ajaiyeoba EO (2016) Alpha-amylase inhibition and brine shrimp lethality activities of nine medicinal plant extracts from South-West Nigerian ethnomedicine. J. Herbs Spices Med. Plants 22: 319-326.

Onyekwelu JC (2001) Growth Characteristics and Management Scenarios for Plantation-Grown Gmelina arborea and Nauclea diderrichii in South-Western Nigeria. Hieronymus Verlag, Munich, 196.

Onyekwelu JC, EI Kateb H, Stimn B and Mosand R (2003) Growth characteristics of Nauclea diderrichii (De Wild.) in unthinned plantations in south-western Nigeria. In: Mosandl R, El Kateb H, Stimn B, Mosandl R (eds), Waldbau-weltweit. Beitrage Zur Internationalen Waldbauforschung Forstliche Forschungsberichte, Munich, 147-163.

Opuni-Frimpong NY and Opuni-Frimpong E (2012) Nauclea diderrichii (De Wild. \& T.Durand) Merr. [Internet] Record from PROTA4U. Lemmens RHMJ, Louppe D, Oteng-Amoako AA (Eds). PROTA (Plant Resources of Tropical Africa Ressources végétales de l'Afrique tropicale), Wageningen, Netherlands. <http://www.prota4u.org/search.asp >. Accessed 20 January 2021.

Orwa C, Mutua A, Kindt R, Jamnadass R and Simons A (2009) Agroforestree Database:a tree reference and selection guide version 4.0 (http://www.worldagroforestry.org/af/treedb/)

Pei-Kieng M and Wei-Seng H (2019) Rapid in vitro propagation and Efficient Acclimatisation Protocols of Neolamarckia cadamba. Asian J. Plant Sci. 18: 153-163.

Pitekelabou R, Aidam AV and Kokou K (2015) Influence of various carbohydrate on the in vitro micropropagation of Nauclea diderrichii (De Wild \& T. Durand) Merrill, an endangered forest species in Togo. Afr. J. Biotechnol. 14(15): 1283-1289

Pitekelabou R, Aidam AV, Kokou K, Kkoutse AD, Etse KD, Adjonou K, Glato K and Aliaki, E (2015a) In vitro vegetative multiplication of Nauclea diderrichii (De Wild \& T. Durand) Merrill, an endangered forest species in Togo. Int. J. Innovation Sci. Res. 13(2): 474-484.

Towns AM and Van Andel T (2014b) Comparing local perspectives on women's health with statistics on maternal mortality: An ethnobotanical study in Bénin and Gabon. BMC Complement. Altern. Med. 14: 113-122. 